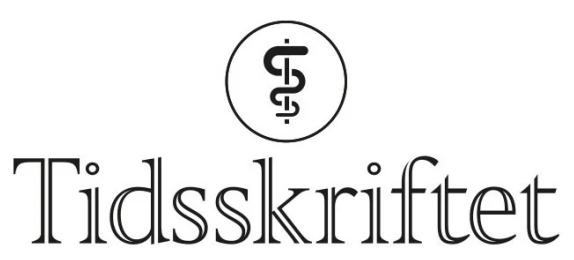

DEN NORSKE LEGEFORENING

\title{
Helse og trygghet først
}

FRA REDAKTØREN

\section{ARE BREAN}

are.brean@tidsskriftet.no

Are Brean er sjefredaktør i Tidsskriftet. Han er ph.d. og spesialist i nevrologi.

\section{De tradisjonelle helsepolitiske sakene har ikke gitt særlig høy temperatur i årets valgkamp. Den største trusselen mot folkehelsen kommer fra annet hold.}

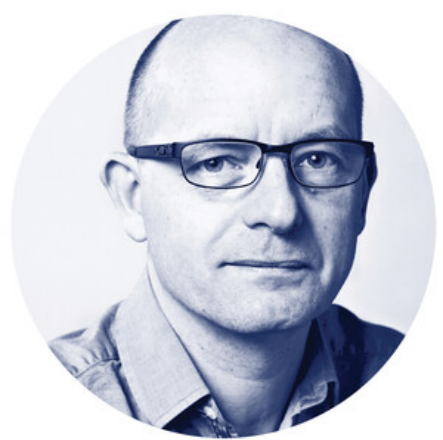

Foto: Einar Nilsen

«Helse og trygghet først». Det var slagordet Legeforeningens landsstyremøte 2020 vedtok som Legeforeningens frontsatsning frem mot stortingsvalget 2021 (1). Og lenge så det ut til at nettopp helse skulle bli den viktigste saken i valgkampen. Koronapandemien demonstrerte hvor viktig en velfungerende offentlig helsetjeneste er. Små og trange nye sykehusbygg, vedlikeholdsetterslepet i eksisterende bygg, underfinansieringen av fastlegeordningen, manglende beredskapslagre og en svekket psykisk helsetjeneste var alle aktuelle og viktige saker. Kantars helsebarometer våren 2020 viste at 50 \% av befolkningen mente at "oppgavene i helsetjenesten» var landets største utfordring (2). Helse var i mars 2020 velgernes nest viktigste sak frem mot stortingsvalget, bare knapt slått av sosiale forskjeller (3). I juni kom Riksrevisjonens knusende rapport om psykiske helsetjenester, som viste at psykisk helsevern fortsatt nedprioriteres og at mange risikerer å ikke få hjelp når de trenger det (4). . Det lå an til at det var helse det skulle handle om, hele veien til stemmeurnene.

Men noe skjedde på veien. Da august 2021 kom, hadde klima gått forbi helse som nest viktigste sak for velgerne, og skatter og avgifter var rangert som nesten like viktig (3). Jo visst har høsten inneholdt helsedebatter, men sammenlignet med andre politikkområder 
har de rene helsepolitiske sakene liksom ikke tatt ordentlig fyr i det offentlige ordskiftet og i valgkampen.

Det er ikke mangel på skillelinjer i helsepolitikken. Spørsmålet er hvor mye de betyr og engasjerer. I spørsmål rundt private helsetilbud er eksempelvis skillelinjene mellom partiene klare og forutsigbare, som Høyre og Arbeiderpartiets krangel rundt fritt behandlingsvalg. I realiteten er denne ordningen av svært liten betydning. Siden fritt behandlingsvalg ble innført i 2015, har til sammen knapt 60 ooo pasienter benyttet seg av $\operatorname{det}(5)$. En ordning som svært få benytter, er lite egnet til å skape engasjement.

Selv der sakene er tunge og viktige, ligger det ikke an til store endringer etter valget uansett valgresultat. Flere partier har eksempelvis åpnet opp for å skrote den sterkt omstridte helseforetaksmodellen. I praksis vil likevel lite skje, uansett valgresultat, all den tid både Høyre og Arbeiderpartiet ønsker å beholde modellen. I tunge verdispørsmål som eggdonasjon, tidlig ultralyd og assistert befruktning for enslige er skillelinjene også tydelige mellom partiene, men siden bioteknologiloven nylig er endret, er det lite trolig med snarlig omkamp. Dermed uteblir de store ideologiske oppgjørene i valgkampen også her.

\section{«Det politiske temaet med størst betydning for helse i årene som kommer, har paradoksalt nok ikke fått noen helsepolitisk oppmerksomhet»}

Da burde det ha vært mer fres over debatten om en fastlegeordning i utvilsom krise. Men her har regjeringen, sterkt tilskyndet av langvarig godt politisk håndverk fra legene selv, allerede lansert en handlingsplan med 1,6 milliarder friske kroner frem mot 2024. Arbeiderpartiet har toppet disse lovnadene med ytterligere 350 millioner friske kroner (ㅁ), og alle andre partier synes endelig å være skjønt enige om at det haster å redde fastlegeordningen. Det gir håp for helsevesenets viktigste fundament, men særlig valgkamptemperatur blir det ikke av slik enighet.

Dermed er det psykisk helse som så langt har skapt mest helsedebatt i valgkampen. Snart åtte år etter at sittende helseminister innførte den gylne regel om større vekst innen rus og psykisk helse enn somatikk, innfris fortsatt ikke dette (4.). Opposisjonen vil ha ny utredning, NOU-prosess eller et nytt utvalg. Helseministeren mener at det ikke er nødvendig. Velgerne har endelig fått et viktig helsepolitisk stridsområde med i alle fall litt temperatur.

Men det politiske temaet med størst betydning for helse i årene som kommer, har paradoksalt nok ikke fått noen helsepolitisk oppmerksomhet i valgkampen så langt. I FNs klimapanels 6. hovedrapport fra begynnelsen av august konkluderer man med at det ikke lenger finnes tvil om at de pågående klimaendringene er menneskeskapte, og at jordens temperatur vil øke med mer enn 1,5 grader - selv med svært lave utslipp de neste årene (7.). Dette vil skape enorme helseutfordringer. Allerede i 2014 kalte WHOs generalsekretær klimaendringer for «det definerende temaet for helse i det 21. århundret» (ㅁ). Siden den gang har helsetruslene blitt enda mer håndgripelige, og den vitenskapelige konsensusen enda større (9.). Likevel er helse så å si fraværende i mye av den norske klimadebatten. Det er symptomatisk at ingen av de over 200 arrangementene om klima og miljø under Arendalsuka i år hadde helse som tema. Skal man tro programmet, var ingen av de store nasjonale helseorganisasjonene innledere eller medarrangører av klimaarrangementene (10). Det er trist. For beslutningene som fattes i den kommende stortingsperioden, vil være avgjørende for om vi klarer å redusere utslippene nok til å avverge vår aller største helsetrussel. Tiden er virkelig kommet for å sette helse og trygghet først. 


\section{LITTERATUR}

1. Nilsen TM. Landsstyremøtet. Helse og trygghet først. Tidsskr Nor Legeforen 11.1.2021. https://tidsskriftet.no/2021/o1/aktuelt-i-foreningen/landsstyremotet-helse-og-trygghet-forst Lest 26.8.2021.

2. Livgard EF. Helsepolitisk barometer 2021. Befolkningens holdninger i helsepolitiske spørsmål. https://kantar.no/globalassets/ekspertiseomrader/politikk-ogsamfunn/helsepolitisk/2021/helsepolitisk-baromter-2021_presentasjon_13-april-2021_forpublisering.pdf Lest 26.8.2021.

3. Aas OI, Murray SM, Christiansen TW. Norske velgere har endret mening. To saker er blitt mye viktigere i løpet av sommeren. Aftenposten 19.8.2021.

https://www.aftenposten.no/norge/politikk/i/k6Mz7A/norske-velgere-har-endret-mening-to-saker-erblitt-mye-viktigere-i-loe Lest 26.8.2021.

4. Riksrevisjonens undersøkelse av psykiske helsetjenester. Dokument 3:13 (2020-2021). https://www.riksrevisjonen.no/globalassets/rapporter/no-2020-2021/psykiske-helsetjenester.pdf Lest 26.8.2021.

5. Moe L. Fritt behandlingsvalg har «i svært liten grad» påvirket ventetider. Dagens Medisin 23.8.2021. https://www.dagensmedisin.no/artikler/2021/o8/23/fritt-behandlingsvalg-har-i-svart-liten-gradpavirket-ventetider/ Lest 26.8.2021.

6. Bulai EM, Tollersrud T, Heggdal Evensen E. Slik vil Støre rydde opp i fastlegekrisen:- Ikke noe nytt, svarer Høie. NRK 11.8.2021. https://www.nrk.no/norge/store-lover-a-redde-fastlegeordningen-1.156o6811 Lest 26.8.2021.

7. Intergovernmental Panel on Climate Change (IPCC). AR6 Climate Change 2021: The Physical Science Basis. https://www.ipcc.ch/report/ar6/wg1/ Lest 26.8.2021.

8. Brean A. Når pasienten er jorden. Tidsskr Nor Legeforen 2015; 135: 2015. [PubMed][CrossRef]

9. Hessen DO. Vi trenger en hippokratisk ed for de ufødte. Tidsskr Nor Legeforen 2021; 141. doi: 10.4045/tidsskr.21.0593. [CrossRef]

10. Arendalsuka 2021. Program. https://program.arendalsuka.no/event/search\#event_2_15540 Lest 26.8.2021.

Publisert: 6. september 2021. Tidsskr Nor Legeforen. DOI: 10.4045/tidsskr.21.06o9

(C) Tidsskrift for Den norske legeforening 2023. Lastet ned fra tidsskriftet.no 26. april 2023. 